\title{
Popular Music Studies and the Problems of Sound, Society and Method
}

\author{
Eliot Bates \\ The University of Birmingham (UK) \\ e.bates@bham.ac.uk
}

\begin{abstract}
Building on Philip Tagg's timely intervention (2011), I investigate four things in relation to three dominant Anglophone popular music studies journals (Popular Music and Society, Popular Music, and the Journal of Popular Music Studies): 1) what interdisciplinarity or multidisciplinarity means within popular music studies, with a particular focus on the sites of research and the place of ethnographic and/or anthropological approaches; 2) the extent to which popular music studies has developed canonic scholarship, and the citation tendencies present within scholarship on both Western and non-Western popular musics; 3) the motivations for two scholarly groups, Dancecult and ASARP, to breakaway from popular music studies; 4 ) the forms of music analysis and the kinds of musical material commonly employed within popular music studies. I suggest that the field would greatly benefit from a true engagement with anthropological theories and methods, and that the "chaotic conceptualization" of musical structuration and the critical discourse would likewise benefit from an attention to recorded sound and production aesthetics.
\end{abstract}

Keywords: popular music studies, anthropology, ethnography, recording production, sound, IASPM

Philip Tagg's timely intervention (2011) raises a host of questions about the successes and shortcomings of popular music studies, thirty years after the founding of IASPM: Is popular music studies truly an interdisciplinary field? Are music and musicians "some kind of troublesome appendage" to popular music studies? Is conventional musicology "a conceptual disaster zone" (7) with a "chaotic conceptualisation of musical structuration" (8), and has popular music studies provided a suitable alternative? His is not the first such work, following in the footsteps of similar retrospectives by Simon Frith (1982) and Sara Cohen (1993). However, Tagg's writings constitute the most stinging critique of the presence - or lack - of interdisciplinarity within popular music studies. Bill Cope and Mary Kalantzis, in an article about knowledge-sharing and knowledge-production in the contemporary digital economy, argue that interdisciplinary approaches are necessary "to disrupt the habitual narrowness of outlook of within-discipline knowledge work, to challenge the ingrained, discipline-bound ways of thinking that produce occlusion as well as insight" (2009). They single out "conventional discipline-defining journals" as being unsuited to this challenge due to their "essential boundary-drawing logic". Taking Tagg, Cohen and Frith's retrospectives as a starting point, and in light of Cope and Kalantzis' vision for a new mode of knowledge-production, I will suggest several ways in which IASPM@Journal may build on the strengths of thirty-plus years of popular music research, while establishing new paradigms and fostering modes of scholarship and 
subjects of analysis that have so far been marginal concerns to the discipline of popular music studies.

For practitioners, the field exists mostly in the journals ${ }^{1}$.

I argue, following Wæver, that journals provide the greatest indicator of the vitality, scope, methodologies, theories, analytical techniques, discursive norms and interdisciplinary inclinations of a field. Academic journals have the potential for a quicker turn-around review and publication process than monograph or edited volume publication, publish articles that often originated as conference papers in the discipline's annual conferences, and typically solicit peer-review from other authors who have contributed to the same journal. Publication in flagship journals is essential for the professional development and career advancement of academic specialists, as it provides the most unequivocal indicator that a scholar's work is deemed worthy of publication by others in their field, and additionally is one of the most important markers of a scholar's track record when applying for competitive research grants or for promotions at research universities. In that regard, Anglophone popular music studies has resided within three primary journals: Popular Music and Society (since 1971), Popular Music (since 1981), and the Journal of Popular Music Studies (since 1988). Other brief-lived journals hinted at alternate epistemologies for the field, for example Worldbeat: An International Journal of Popular Music, which through one ill-fated issue attempted to linguistically and topically internationalize the field, or OneTwoThreeFour which published nine issues with eclectic content including some of the first ethnographic studies of the practice of sampling (Prato, 1990) and MIDI technology (Théberge, 1990) - but the short life of these journals meant these epistemologies did not fully develop at the time. With this in mind, in this article I for the most part restrict my analysis of the field of popular music studies to articles in the three primary journals listed above, fully aware that scholarship on popular music is also published in other journals where it occupies a marginal, rather than dominant, status.

My interest in this article is to examine four things. First, what does interdisciplinarity or multidisciplinarity mean within popular music studies, and what is the place of ethnographic and/or anthropological approaches within the field? As I will show, although the words "anthropology" or "ethnography" appear (usually once) in hundreds of articles, and an increasing number of articles on non-Western popular musics written by ethnomusicologists grapple with anthropological theories and methods, with preciously few exceptions anthropology and ethnography (and more broadly, all social sciences) have not been a significant part of the study of Anglophone popular musics in the UK, US and Canada. I suggest that this absence is largely responsible for the lack of analysis of social/cultural context, and thus twenty years later Tagg and Negus' question - "meaning for whom?" - is still unanswered (1992). Popular music studies continues to downplay or ignore the role music plays in life and society, which Sara Cohen attributed to an emphasis on "structures, texts or products" rather than a "focus upon people and their musical practices and processes" (1993: 127). As Thomas Solomon argues, when contexts or audiences are considered within what he terms the "sociological literature within popular music studies" (2012: 86), this is to the exclusion of any consideration of texts or meaning. Popular music is undeniably an object of multidisciplinary interest, but has this resulted in a true interdisciplinarity?

Second, I am interested in the extent to which popular music studies has developed a body of canonic scholarship, and also in the relation between the scholarship about a geographically limited subset of Western popular musics and scholarship about "nonWestern" popular musics and/or global genres situated outside of "the West". I uncovered a disturbing trend: despite the steady increase in work concerning "nonWestern" popular musics, this work is rarely if ever cited by scholars who write about popular music in the US, UK and Canada. The field has come to replicate the Westfocus and hegemonic tendencies of historical musicology - quite a deviation from the original values of IASPM. Regarding the geographical specificities of the hegemonic 
tendencies at play, I must clarify two terms: "the West" and "Anglophone", and how they fit within my study. I single out scholarship written about Anglophone popular music in the US, the UK and Canada because it comprises a cohesive body of work that features a striking consistency regarding citation patterns, not since I wish to perpetuate a sense that these countries actually connote "the West". Visibly at the margins of this work, therefore, are non-Anglophone popular musics in the same countries (for example, indigenous and/or minority popular musics in the Americas or the UK) and Anglophone popular music forms from other countries (notably but not limited to the rest of Europe, Australasia and the Caribbean). Also marginalized are "other" journals; for example, the Australian journal Perfect Beat is internationally distributed but rarely cited in the "big three" journals. In light of the vibrancy of the field of popular music studies within other countries (especially Australia, New Zealand, Jamaica, Brazil and Mexico), this situation is especially surprising. ${ }^{2}$

Third, with the backdrop of these disciplinary norms in mind, I also will consider two "breakaway" groups of scholars and the journals they have published. The need for new societies/journals arose not solely due to topical concerns, as the primary subjects of Dancecult (electronic dance music) and of ASARP, the Association for the Art of Record Production (popular music recording production) would seemingly fall squarely within the milieu of the existing popular music journals. As I will argue, Dancecult became necessary since a group of scholars found that their debates about theory and methodology, in particular anthropological approaches to the study of experience, were not shared with popular music scholars looking at other styles and scenes. Similarly, ASARP emerged in the wake of a long-standing lack of attention on studio production, work, professionals, techniques and technologies within popular music studies - and a paucity of multimode analyses of recorded music. Not surprisingly, from the start these fields attracted a significant amount of core scholarship that would have been topically or geographically marginal within other popular music studies journals.

Fourth, and more specifically addressing Tagg's suggestions for the field, I will explore the forms of music analysis and the kinds of musical material commonly employed within popular music studies, and many that are not. I was particularly struck by Franco Fabbri's email cited in the article:

[Music] and musicians seem to have become some kind of troublesome appendage to popular music studies... Where is music and where are the musicians? Can researchers learn something from them, or are musicians some kind of unnecessary appendix of popular music studies? (Fabbri in Tagg 2011: 4).

Tagg diagnoses the problem as the "Great Epistemic Divide in European culture between notions of art and science, subjective and objective, poïesis and aesthesis" (ibid. 5) and suggests several techniques for describing music in relation to video scenes, some of which stem from the musematic analysis approach he pioneered in the late 1970s (Tagg, 1979). ${ }^{3}$ While I feel this is certainly part of the problem and presents one possible solution, I suggest an alternative, that the biggest contributing factor to musicology's "chaotic conceptualisation of musical structuration" (ibid. 8) is the widespread lack of engagement with the tools, techniques, workflows, and critical vocabulary of recording production, and with the audible aesthetics of recorded sound. No student of historical musicology could ever graduate without having at least a basic proficiency in music theory and analysis, ear training and piano performance, a pedagogical convention that directly results in the perplexing kinds of melodic, rhythmic and harmonic analyses Tagg notes comprise the bulk of popular music analysis. I argue that an equivalent baseline for popular music studies would include the ability to understand recorded music theory and analysis, ear training skills geared towards hearing production techniques (also called "reverse-engineering" the recording process), and a basic practical knowledge of how recording work, studio musicianship and production/arrangement is done. 
As a considerable amount of popular music studies depends upon criticism of commercially-released recordings, popular music studies scholarship should demonstrate a familiarity with the environments in which these recordings were created (such as, audio recording and film studios, or live concert stages), the sorts of professionals who help create these recordings (engineers, editors, studio musicians, arrangers, producers, foley artists, field recordists, FOH mixers), and the effect of the social networks and interaction of these and other individuals (for example, artist managers, publicists, critics) on the resulting musical product. I suggest these not with the intention of throwing up barriers to entry or valorizing technical work, but rather since recording techniques provide us a valuable critical vocabulary that would enrich musical analysis, bring scholarship more in dialogue with actual practitioners, and broaden the discursive terrain of popular music studies. As Will Straw has noted in relation to the work of Georgina Born, a shift away from the "audience-centred populism of music cultural studies and media ethnography" and towards the "rich analytic traditions concerned with the complexity of cultural production" (2010: 210) is necessary in order to describe any of the complexity of society, culture or individual agency. In the fourth section I will suggest a few terms from the field of recording production (reverberation, feedback, compression) that I feel have a strong potential.

The data for this article began with quantitative analysis of term inclusion within the three major Anglophone popular music studies journals but shifted to qualitative analysis. For example, as a start towards understanding the place of anthropology/ ethnography in popular music studies, I tracked down every instance of words including "anthropology," "anthropological," "ethnography" and "ethnographic" within the body of feature and editorial articles published within the journals since their inception. ${ }^{4}$ Shifting to qualitative analysis, I then analyzed the context in which a term was used in each article, and was surprised to discover consistent patterns of term usage. To assess the place of scholarship on non-Western popular musics and global popular musics outside of the West within the discipline, I found the fifty most cited articles on such topics within each journal, then used Google Scholar analytics and the citations features of Proquest/Wiley-Blackwell's search databases to find the full list of articles that cited these. I also found useful several retrospective analyses of the topical and disciplinary leanings of popular music studies conducted at different points in the history of the field. I must stress, again, that my article is primarily concerned with the codification of the discipline of popular music studies as it has unfolded within the pages of three journals, which I will later compare with alternative epistemologies in breakaway fields.

\section{Anthropology, ethnography and the limits of popular music studies' interdisciplinary compass}

Simon Frith (1982) once bemoaned the fact that students would rather sit in the library and study popular music (mainly punk) in terms of the appropriate cultural theory, than conduct ethnographic research which would treat popular music as social practice and process. Ten years later the literature on popular music studies is still lacking in ethnography. (Cohen 1993: 123).

Twenty years after Cohen's seminal outline of a method and theory for the ethnography of popular music the situation has only partly changed. Although at the time there had been few studies of popular music traditions outside of Western Europe and North America, today popular music studies journals publish a significant number of ethnographies on outside popular music forms, usually written by ethnomusicologists who conducted long-term participant-observation research. I'll briefly mention some of the most notable recent contributions in this vein. David Novak's article on Japanese kissa (coffeehouses) and the shift from jazz listening to noise listening shows the importance of studying locally situated practices of listening to recorded and mediated music forms, in particular how listeners' interpretations "are as filled with interpretable meaning as the sonic objects themselves" (2008: 16). Kevin Dawe's work (2003) on the 
Cretan lyra (a small pear-shaped fiddle) illustrates the importance of attending to the plurality of meanings of musics and instruments, with a specific interest in how lyras became masculinized and part of the body politic of Crete in the late twentieth century. Thomas Solomon's analysis of hip hop in Istanbul focuses on local discourses of authenticity and place, which ties into "debates about popular musics in the context of globalization" (2005: 2) yet articulates a local specificity about these discourses that undermines any homogenizing tendencies of globalization. Alexander Dent (2005) uses linguistic anthropology models to analyze a Brazilian cover of the country hit "Achy Breaky Heart". What connects such disparate work is an attention to social practice and process - one that is notably explicated through ethnography.

Ethnography - literally meaning making notes about culture - is a writing genre that characterizes much of contemporary anthropology, ethnomusicology and science and technology studies. According to James Clifford, the author of many influential writings on ethnography, there are six ways to determine ethnographic writing: contextually, rhetorically, institutionally, generically, politically, and historically (1986: 6). Ethnography was a major site of critique and self-reflection during and following the 1970s-1980s crisis in anthropology, and Clifford singles out a trend towards "a specification of discourses in ethnography: who writes? When and where? With or to whom? Under what institutional and historical constraints?" (13). Clifford notes that within contemporary ethnographies "once cultures are no longer prefigured visually as objects, theaters, texts - it becomes possible to think of a cultural poetics that is an interplay of voices, of positioned utterances" (12), a point which partially articulates the difference between popular music studies texts and ethnographic ones.

Within the pages of the popular music studies journals analysed, few ethnographic articles concern the musics of Western Europe, Canada and the US. Two monographs that suggest what such a study might look like include Sara Cohen's work on rock bands in Liverpool (1991), and Ruth Finnegan's study of Milton Keynes' music scenes and art worlds (1989). These exemplary ethnographies of musical life in England are often cited but rarely imitated. Likewise, Harris Berger's phenomenologicalethnomusicological analyses of rock $(1999,2009)$ provide another model for an ethnographic approach that has yet to be emulated. To be clear, ethnographic approaches to the hegemonic popular musics of the world do exist and are published in journals such as JARP and Dancecult (I will discuss these in the third section) and occasionally in the ethnomusicology journals. However, as Cohen noted, popular music studies, then and now, "has been more influenced by linguistic, semiotic and musicological traditions than by the social sciences, and has relied upon textual sources and analysis" (1993: 126).

Even simple mentions of the term anthropology are fleeting at best, and embarrassingly reductive at their worst, suggesting that many popular music studies scholars may have little concept of what an anthropological study of popular music would actually entail. In several articles the only incidence is as a part of a sprawling comma-delimited list of disciplines (for example, Brooks 2010: 99; Jackaway 1999: 128; Duffett 2003: 515). In an article on Greek rebetika subcultures, Janet Sarbanes sets up a false dichotomy between "anthropological" and "subcultural" approaches to music, inaccurately framing Tia DeNora and Simon Frith's works as "anthropological" due to their supposed focus on music "as a device of social ordering," while the author's purported project of "locating in subcultural aesthetic practice an(other) mode of sociality... that allows for both collectivity and individual difference and freedom" (2006: 19) is suggested as a framework outside of the routes permitted by anthropological theory and method. In an equally puzzling indictment, literary critic Geoffrey Jacques suggests that the biggest problem with Ken Burns' documentary on jazz is that "Burns seems to want to turn jazz into a subset of anthropology and ethnography, rather than approaching it as an art form with its own historical, social, and aesthetic parameters" (2001: 223). While many aspects of anthropology merit 
critique, including its complicity in colonialism (Asad, 1973), the asymmetrical power dynamics implied in the field's persistence of constructing and deconstructing "others" (Grenier and Guilbault, 1990), the political epistemologies of "ethnographic realism" (Marcus and Fischer 1986: 23), and the problematic conceptualization of subjectivity and the subject (Ortner, 2006), nonetheless anthropology still provides an immense array of theoretical and methodological resources for analyzing people - and the music they make.

In other articles, anthropology or ethnography is apparently an important part of the lives of the subjects, yet these revelations only receive a passing mention. Thomas Sheehan's article on lggy Pop includes a passage where lggy recounts "cadging things from anthropology books for the conception of my band" (2007: 136). The inimitable record collector Harry Smith first started his collecting efforts while a graduate student in anthropology at the University of Washington (Dougan 2006: 49). William Maxwell, citing Robert O'Meally's writings on jazz writer and novelist Ralph Ellison, suggests that "Ellison's ideal of the blues-based public jazz rite stemmed as much from his study of the 'myth and ritual' school of Cambridge anthropology as from his days as a jitterbugging participant-observer" (Maxwell 2004: 47). In an Adornian take on Frank Zappa, David Wragg highlights Zappa's "detached, observational attitude" towards society through reference to his "field recordings" of former mental patient Larry Fischer, but critiques the objectivity of this "ethnography" on the basis of its subsequent commercialization (Wragg 2001: 211). ${ }^{5}$ The list goes on: Yo Yo Ma, Tracy Chapman, Will Champion (Coldplay), Jennifer Nettles (Sugarland), and Greg Graffin (Bad Religion) all have anthropology degrees, and anthropological studies were central to the creative work and vision of many artists in the industrial genre, such as SPK, Non, Z'ev, and Monte Cazazza; see Juno and Vale (1983), Vale and Juno (1989). Anthropology is seemingly more important to the practitioners of popular music than to its scholars. But how does anthropology figure into these artists' creative work or its reception, and what precisely is meant by anthropology in these contexts? Here I think it would be fruitful to compare anthropology in popular music with the art school experience of a generation of British popular musicians, as documented by Simon Frith and Howard Horne (1987).

Another indicator of the relation between anthropology and popular music studies is the place of popular music studies scholarship within anthropology journals. Not surprisingly, for the most part popular music studies journal articles are not cited within anthropology, with the exception of one citation in an article by Charles Keil (1985) that deals with topics related to popular music, and the occasional instances when an article about popular music outside the west is cited in an anthropology article due to the geographical/topical focus (but not for theoretical or methodological considerations). In other words, anthropology has not perceived work emerging from popular music studies as contributions to the anthropological literature, even among the many anthropologists who study popular culture or music.

Within popular music studies journal articles, particularly following the cultural studies/critical theory turn, one finds citations of the sorts of literature often cited by anthropologists (for example, Bourdieu, de Certeau), but this does not imply a dialogic engagement with any body of anthropological theory, and the lack of citations of popular music studies efforts by anthropologists contributes to a sense that this interest is limited and a one-way street. For example, Bourdieu's theoretical writings on distinction, habitus, field and cultural capital make numerous cameo appearances, but in only one article (Dawe, 2003) does the author provide a genealogy of the terms themselves, such as a comparison of Bourdieu's concept of habitus with Aristotelian or Maussian concepts of the same, and in no articles is there a consideration of the context in which Bourdieu's theories emerged - his ethnographic work in France and Algeria. I believe this decontextualization and selective appropriation of critical theory constitutes another factor that dissuades anthropologists from paying much attention to 
anthropological nods in popular music studies, as they do not follow anthropological (or broader social science) norms for such engagement, which ties into Clifford's discussion of the institutional character of ethnography. A lack of self-reflective methodology sections within popular music studies writing also serves to suggest that popular music studies' interdisciplinary/multidisciplinary scope does not encompass anthropology. Jonathan Sterne eloquently argued that Bourdieu could be of particular relevance to the field of science and technology studies due to Bourdieu's insistence on the careful construction of "the object" of study, and noted that "the choice of theoretical stakes; the ideas, events, and processes included and excluded from the object of study; the approaches or 'methods' to be used; and the conceptualization of that object within a larger field of objects" constitute "the most important part of social research" (Sterne 2003: 370). A similar self-reflection would be invaluable for popular music studies, too.

\section{Others, othering and the development of a canon}

Within the discipline and the pages of individual journals, much could be done to increase the sharing of ideas, theories, and methodologies. All the journals today include a substantive number of articles on popular musics outside of UK-US-Canada, and scholars of such musics frequently cite articles concerning music within and outside their own region, yet such is not the case for scholars focusing on these canonical repertoires. I could only find one instance in the history of the popular music journals where a scholar writing about UK, Canadian or US popular music cited an article in a popular music studies journal concerning "outside" or "other" music - Chris Atton's (2011) citation of David Novak's work on Japanese noise genres.

In other words, popular music studies seemingly consists of two groups of scholars: those who work on a subset of Anglophone popular music forms (what Tagg calls the "NATO Association for the Study of Popular Music" (1985a: 503)) and have no disciplinary pressure or apparent need to be aware of the scholarship on nonAnglophone musics, musics transpiring in other countries, or popular music studies traditions from elsewhere in the world; and those who work on other musics, who need to be aware not only of the scholarship into their chosen region, but also scholarship about the music style regardless of location, and the conceptual and rhetorical norms established within the "NATO Association". This chasm seems eerily familiar to the one between historical musicology and ethnomusicology, especially in the US where ethnomusicologists are expected to have a competent knowledge of Western European music history and theory in addition to expertise in the music, history and cultural life of their chosen region (and familiarity with additional regions as well), while historical musicologists are rarely expected to have taken anything more than a onesemester introduction either to "world music" or the discipline of ethnomusicology. This is not surprising, as Sammie Wicks discovered that more than 97 percent of music department course offerings at research universities in the continental United States covered "topics in the elite Western tradition" (1998: 62) to the exclusion of American music and all the rest of the world's musics.

But within the context of popular music studies this is especially surprising, if not due to the already marginal status of the field within North American music departments, then due to the fact that most of the musical genres in question are effectively global, translocal or transnational in scope - a situation that has been the case at least since the tango craze of the 1910s (Goertzen and Azzi, 1999). Popular music forms in foreign countries are not simply imitative of "Western" musical forms (for example, center $\rightarrow$ periphery), as many directly influence "Western" popular music (periphery $\rightarrow$ center). "Western" artists are significantly engaged in foreign popular music forms, such as Swizz Beatz' K-pop productions, Timbaland's production of J-pop star Hikaru Utada, Jay-Z's remixes and covers of bhangra artist Panjabi MC, or the numerous long-term collaborations between artists as diverse as Robert Plant, Sting, 
Bill Laswell or Paul Simon with artists based in Africa, Asia and the Caribbean. Therefore it seems time for scholarship on popular music to match its subject matter and move, thematically, theoretically and methodologically, beyond a center-periphery model, and beyond its particular chosen hegemony of Anglophone rock/pop criticism.

\section{Margins and schisms: the formation of IASPM, Dancecult and ASARP}

The formation of a new society or new journal is an exciting moment, bringing into sharp relief the insufficiencies of extant scholarly modes and indicating the emergence of new ones. Such was the case when the Society for Ethnomusicology (SEM) was "founded," somewhat by chance, in 1952 by Alan Merriam, David McAllester, Willard Rhodes, and Charles Seeger. The story of the foundation of "American ethnomusicology" tends to emphasize ethnomusicology's anthropological leanings and split from historical musicology, but as Bruno Nettl convincingly argues, Alan Merriam more pertinently perceived this as a split from the International Folk Music Council and the discipline of folklore, which in his perception was overly focused on "music alone," and moreover a "small segment of the music of any society" (2010: 143).

The formation of popular music studies, which happened in stages, is worth repeating, and has similarities to the genesis of ethnomusicology. In 1971, the Popular Culture Association (PCA) broke off from the field of American studies due to the latter's excessive focus on "the then existing canon of literary writers such as Melville, Hawthorne, and Whitman" (PCAACA, 2013: web source). Popular music studies in 1971 had a modest beginning, consisting of four panels, speeches/seminars by Bill Malone and David Madden, and supplementary performances (Anon, 1971). But the lack of space in the Journal of Popular Culture necessitated the formation of a separate journal for music-related writings: Popular Music and Society (Browne, 1971). This particular "American" tradition therefore was not initially at the margins of existing musicologies, but rather at the margins of American literary criticism.

Across the Atlantic nine years later, and based on the perception that "if we did not wish to end up as the marginal 'popular' section of the IMC [International Music Council], we also felt it wise to avoid becoming the marginal 'music' section of the IAMCR (International Association for Mass Communication Research)" (Tagg, 1985b), discussions about the formation of an international society happened at the first International Conference on Popular Music Research, held in Amsterdam and organized by Philip Tagg, Gerard Kempers and David Horn. This event coincided with Richard Middleton's editorial efforts in launching the UK-based journal Popular Music, and in the aftermath, IASPM quickly grew to include hundreds of members in thirty countries. The US branch of IASPM absorbed the PCA/literary criticism contingent, and after a couple of experimental journals focused their efforts on the Journal of Popular Music Studies.

For both SEM and IASPM, the impetus to organize included both topical concerns, for example kinds of music that were not adequately addressed within existing frameworks, and methodological/theoretical divergences. (American) ethnomusicology formed largely due to the lack of acceptance of anthropological approaches within other societies; popular music studies (at least in Tagg's retrospectives) required a form of musical analysis that wasn't within extant musicological models (Tagg, 1985b). Yet both also formed in the margins of established, hegemonic disciplines. Thirty years later it appears popular music studies has come to form its own hegemony - and its own margins.

Dancecult was founded in 2005, first as an electronic mailing list devoted to the discussion of research into electronic dance music cultures (EDMCs), later as a collaborative bibliography project, and then in 2009 as an open-access peer-reviewed journal entitled Dancecult: Journal of Electronic Dance Music Culture. I asked the journal's co-founder and first executive editor, Graham St John, about his motivations 
towards creating a new journal, and his sense of the position of Dancecult in relation to extant popular music journals:

Having published widely to that point, including several edited collections, as well as articles in various journals, I was intimately familiar with and repulsed by the corporate ownership of scholarship, a situation that is not easily contested, especially if you're on a $24 / 7$ teaching position and you need to publish for tenure or promotion, circumstances that the academic publishing industry continues to capitalise on. I wanted an intervention that allowed scholars to virtually convene at a professional venue that was not profiting from the publication of state (and sometimes privately) funded research, as is the situation with most journals where prestige comes at a severe cost. I also wanted to help create a venue that would be the chief journal for the growing network of EDMC studies, a rather disparate and cross disciplinary phenomenon that dwells on the margins of popular music studies where it flourishes like fungus in dim light. ${ }^{6}$

One of the defining features of the majority of articles in Dancecult is the strong presence of participant-observation research and ethnographic writing, and an overwhelming emphasis on the experience of the live performance of EDM, at festivals, clubs, raves, bedrooms, or other spaces. Part of this is due to the writings and editorial work of St John, an anthropologist of EDMCs deeply indebted to the legacy of Victor Turner, even as much of his writing has staged a struggle with Turner's formulations of concepts of the limen/liminality (St John 2001: 2008), communitas (2012) and synchronicity (2009). Perhaps due to the immediately obvious mass-social nature of EDM performances and preponderance of festivals (Schmidt, 2012) or the utopian political ideologies of many EDM communities and their precarious relation to extant criminal justice systems (Anderson, 2009), many social anthropologists and sociologists have been drawn to the study of EDMCs, but I believe that EDM's relative de-emphasis of lyrics or texts also serves to dissuade scholars from approaches used in other branches of popular music studies. By all appearances, Dancecult is what popular music studies journals might be if anthropology were part of the interdisciplinary compass, and if the primary objects of analysis were the social formations constituted at events. However, continuing a problem that generally affects anthropological approaches to music, within the journal very little attention has been paid to musical sound or structure, nor to the production/producers of music that DJs subsequently spin, effectively rendering music and sound contingent or immaterial.

The Association for the Study of Record Production began in 2005 as a series of annual conferences (ARP), later publishing an open-access peer-reviewed journal and forming a professional association. Simon Frith summarized the need for the conferences and the Journal on the Art of Record Production (JARP) in the inaugural issue:

Record production has also been a neglected topic in popular music studies. A few producers (Phil Spector, Joe Meek, George Martin) have been the subject of journalistic attention; the work of most has been sparsely documented. As I discovered when putting together a 4 volume collection of key essays in popular music studies, it took many years for the pioneering work of Edward Kealy and Antoine Hennion to be followed up academically. And even now, as Jay Hodgson argues in his paper here (and despite the work of such scholars as Paul Théberge, Albin Zak and Thomas Porcello) 'recording practice' is almost always subordinated analytically to 'live practice' in popular musicology. One important reason for this journal now, then, is to keep in play this exchange between academics and practitioners. (Frith, 2007).

One defining feature of most articles in JARP is the assumption that recordings are not intact entities but rather processes, the result of performances, editing, engineering, negotiations, arrangement, management and production, kinds of work which vary considerably between sites and through different eras of recording production. Another feature is an insistence on new modes of musical analysis that regard production and engineering decisions and techniques not as extrinsic to the musical work, but rather as constitutive of musical composition in the age of mechanical reproduction. Another 
hint of the psychological impetus towards the formation of a new society is suggested by Albin Zak, "lonesome as I was talking to myself about reverb and EQ as elements of musical composition" (2012), who was saved from his lonesomeness by the first ARP conference and a panel entitled "the musicology of record production".

Scholarship in JARP seems to exhibit much of the heterogeneity that Tagg seems to advocate. Among the aesthetic/analytical works are a number that analyze issues of spatialization (MacFarlane 2009; Moylan 2009), dynamics and dynamic range (Hodgson, 2011), phase (Paterson, 2007), and genre-specific mixing aesthetics (Howard 2008; Mynett 2012). A number of works consider perceptual issues, including listener perception of mp3s (Gerber, 2011), the effect of spatialization techniques on the emotional arousal of listeners (Fletcher, 2011) and the kinesthetic/synesthetic practices of audio engineers (Bates, 2009). Sociological work within JARP has tended either towards the sociology of technology, for example a study of pop producers' perceptions of competing technological paradigms (Bennett, 2009), or to the sociology of social creativity (Mclntyre 2008; Morrow 2012). While much of the work is somewhat ethnographic and rooted in observations of specific recording sessions, anthropological and ethnomusicological approaches have yet to gain much hold within the journal or the conferences. Nevertheless, JARP hints at what popular music studies journals might be if they seriously engaged in recorded music analysis or possessed a critical vocabulary for assessing any of the myriad aspects of recording production - the subject of the next section.

\section{Studio discourse}

The study of recording has been a marginal concern in the academic study of music. (Frith, 2007).

One measure of the methodological/theoretical/topical lacunae of popular music studies concerns the place of audio engineering terminology, both of recorded music (album/video/TV/film) and live sound reinforcement. Many journals are uncomfortable with terms such as equalization, compression, limiting, reverb, mastering, delay, phase, latency, condenser microphone, and proximity effect, requiring authors to explain and define them. Nearly all of these terms have been in the standard vocabulary of audio engineers, studio musicians, record producers, A\&R representatives and other music professionals for eighty or more years. Other more "recent" terms in the last 20-60 years, including chorusing, flanging, vocoding, phasing, plugins, headroom or slapback echo are equally central to the discourse in "contemporary" recorded sound production, but similarly are absent in many journals.

It is impossible to understand the very materiality or musicality, let alone the very existence of recorded music itself, without having at least a basic familiarity with the phenomena indexed by each of these terms. There has never been an easier or more affordable time for the curious to learn about audio engineering. Music technology is readily available, affordable and works on standard home computer hardware. Numerous YouTube videos provide instruction in using and hearing compression, EQ, chorusing, reverb, delay, gated toms, and slapback echo.

This terminology, though the core of popular music production, does not form the core of popular music studies. While the term "space" is often used in the abstract as a synonym to milieu or context, it has quite specific meanings within recording studios or concert halls, in terms of its effects on the musical and social practices that happen within, or numerous acoustical attributes such as early reflections, natural reverberation, standing waves, room modes, low-frequency buildup, diffusion, and absorption that leave audible traces on all recorded sound (Bates, 2012). The term reverberation, in sound studies writing, tends to refer to the effect sound has when it moves into different cultural milieus, making reverberation the soundscape equivalent 
of the flows through Appadurai's ideoscapes and finanscapes (1990). Yet reverberation (and acoustics) is anything but an abstract, undifferentiated flow.

What is striking about reverberation, is that all sound recorded or played back in that space comes to indelibly possess this unique sonic signature, making the space immediately identifiable to the listener. When we hear Mumia Abu-Jamal's Radio Essays or All Things Censored, we are immediately confronted with the sound of the small concrete room in the SCl Greene County prison where Mumia was on death row for years. The unique "raw and folksy" sound of Tom Waits' recordings, starting with the 1992 Grammy-winning album Bone Machine, has much to do with the reverberation characteristics of a storage room Waits discovered at Prairie Sun Studios in Cotati, California, now called "The Waits Room," which was used not just for tracking but also as an echo chamber. Reverberation, rather than an abstract flow, is better theorized as the indelibility and identifiability of acoustic space; it stands in partial opposition to the concept of schizophonia (Schafer 1977: 90; Feld 1994), suggesting that even when sounds are removed from their original context, they still retain audible traces of their original space and place.

My own process for thinking through these issues of sound and recorded aesthetics, what Albin Zak terms the "poetics of rock" (2001), is in part inspired by a few scholars who would likely be labeled as scholars of "sound studies". Jeremy Wallach argues for the importance of understanding the sonic experience of recorded music, and that the techniques used to produce an aesthetic of uncompromising loudness (compression, scooped midranges in guitars) themselves constitute a politics (2003). Thomas Porcello treats the analog tape recording of print-through as a "metaphor for cumulative listening experiences engendered in the mediated social spaces of musical encounter" (1998: 486), part of a broader project in analyzing the phenomenology of experience. My own work examined two aesthetic properties of albums produced digitally in Turkey, parlak (shine) and büyük ses (big sound), showing how audible aesthetics contain not just a musical register but rather are a "product of social interactions" (2010: 100). The poetics of popular music, then, is rooted in sound and process.

Another term with much potential for a critical discourse rooted in the studio/ live concert experience is feedback. Feedback tends to be used as a synonym for "interaction" or "interlocution", while it is more productively analyzed in a sonic context as a phenomenon where a system's output is fed back into its input. A sociotechnical concept of feedback was suggested by François Ribac to explain the ways in which individuals are influenced both by the technologies they use and the social formations in which they work, while simultaneously contributing to these sociotechnical systems (2007). His Latourian take on feedback is refreshing, as is his analysis of feedback in Elvis' early recordings, but I wish to clarify a few things concerning the sonic phenomenon and suggest additional ways of bringing feedback into critical theory. Amplifier feedback, more precisely termed a feedback loop, has the sound character it does in part since the guitar pickup receives the amplified sound after some amount of time delay (perhaps as little as $1 \mathrm{~ms}$ ), and the sound of the source mixed with the delayed version is subjected again to feedback after the same amount of time delay. Due to the short time intervals and hundreds of iterations of output feeding input, many of the lower frequencies of the signal effectively null out, leaving a reduced number of frequencies mainly concentrated in the higher harmonics and a new timbre that derives from the original sound while ontologically constituting something new. While this is not a complete description of feedback, this aspect has the metaphoric potential to be used to discuss anything with a recursive logic, especially recursion that results in a distortion of the original intent/source while retaining traces of the original. The recursive nature of feedback is a closed-loop, insular system that precludes a discursive or dialogic encounter, and this recursion and distortion results in an excess of the original source that threatens to destroy the original intent/source yet creates something new in the process. 
Turning away from poetics, it would also seem that a true scholarly understanding of any work of recorded music that aims to be anything other than music criticism with footnotes must be rooted in an understanding of the socio-technical-musical assemblage in which that work was created. I will not call this the context of production, as context implies a contingency and that the object can be removed from one context and placed in another (recontextualized), which might be partly true for reception but is emphatically not the case for production. However, without understanding the technological capacities and limitations, the norms of sociotechnical interactions, and the specific modes of collective creativity within any production milieu, we cannot understand the artist's experience or the sorts of creative decisions that contributed to the production of a work. At the center of Louise Meintjes' ethnography of the production of the South African mbaqanga popular music genre is an analysis of the power relations and systems of exclusion at play in Gallo Studios, as the studio "offers a prism into late capitalist, late apartheid experience and into how global popular culture flows are activated within the context of local politics" (2003: 9). Two articles on the Brill building (Scheurer 1996; Inglis 2003) provide a foundation for understanding that legendary New York songwriting institution and suggest the importance of studying creativity as a social rather than individual process. Yet, similar attention has not been afforded to the most prolific studio institutions such as the loose group of Los Angeles session musicians known as the Wrecking Crew - performers and arrangers of the backing tracks for thousands of singles including all of Phil Spector's hits and much of the work of the Everly Brothers, Beach Boys, Sonny \& Cher, The Fifth Dimension and countless other artists (Hartman, 2012). The Wrecking Crew have yet to be mentioned in the popular music studies journals. Productive work in this vein could draw on recently published memoirs from audio engineers whose careers spanned four decades of popular music history, such as those of Ken Scott (Scott and Owinski, 2012) and Phill Brown (2010).

Another recurring theme is the preponderance of "happy accidents", mistakes made during editing or tracking that were left in but now are regarded as brilliant creative "decisions". Charles Kronengold (2005) noted something similar in regard to the "hooks" of songs, and suggested that popular music studies should not rely on the assumption that the final sound of recorded music was intentional. While his point is certainly valid, and an example of one of the many aspects of production that should be brought into greater dialogue with popular music studies, unfortunately his analysis depends on his own interpretive assessment of both the "hook" and what connotes an "accident," and does not result from evidence that such moments in their inception were either hooks or accidents - such as the memoirs of Scott and Brown provide, or such as that produced from ethnographic data derived from long-term participant observation. My broader point is that musical creativity and cultural production are inextricable from the idiosyncratic and unpredictable assemblage of the studio (or multiple studios, in the case of some albums); text is inextricable from context.

\section{Conclusion}

Neither the inclusion of anthropological methods/theories nor the expansion of analysis into the realm of recording aesthetics, in isolation, will revolutionize the field of popular music studies, nor prepare it to answer some of the key questions about popular music and society. The root problem that ties together the specific issues I discussed earlier (and many additional ones) is how the object of study is constituted and assembled. When objects are constituted and assembled in such a way that they facilitate the exclusion of inconvenient truths (for example, the internationalization of artists and their musical forms, the presence of alternate modes of theorization, or the limitations of existing modes of analysis) then that choice is a political one, just as the choice to exclude or marginalize popular, American or non-European art music repertoires from music curricula is a political choice. Forming new disciplines that then 
come to quickly define their own margins and boundaries does not appear to be the most expedient solution in the long term, even if it produces some interesting scholarship in the short term, not the least because of the great competition for the meager financial resources available for humanities and social science research. However, such schisms do bring into relief the insufficiencies within and politics of existing fields, and as such provide a valuable source of reflection and self-critique for scholars within all of the musicologies. Ultimately, for the scholarly study of popular music to make a broader contribution to humanities and the social sciences, it will need to develop a more suitable critical vocabulary, or in the words of Tagg, will need "to grow up, to face extramural reality, and (...) to set its conceptual house in order" (2011: 8).

\section{Endnotes}

${ }^{1}$ (Wæver 1998: 697).

2 I also noted that some of the most significant popular music studies scholars in Australia and New Zealand have never published in the big three journals (for example, Geoff Stahl, Karl Neuenfeldt), and others have not published in any of them for over fifteen years (for example, Andy Bennett). I do not know the specific reasons for this, but I do wish to point out that the scholarship of these three scholars has a strong fieldwork component and stylistically is ethnographic rather than literary criticism.

${ }^{3}$ It is outside of the scope of my essay to debate the kinds of music that merit analysis or what should be rightfully included within the sonic compass of popular music. Yet, in considering the place of TV, film and advertising music - woefully understudied as they are - within popular music studies, I cannot help but recall Jeremy Wallach's provocative statement that "recorded music lacks visuals because they are unnecessary" (2003: 40). I believe we need both an understanding of how sound works on listeners in the absence of visual referents, and how sound works with the visual to create different senses of affect, what Michael Chion terms "audio-vision" (1994).

${ }^{4}$ The words "anthropology" or "anthropological" appear in the body text or footnotes of 35 editorials or feature articles in Popular Music, 17 in the Journal of Popular Music Studies, and only in 9 of Popular Music and Society. However, this does not show that anthropology is more central to the journal Popular Music, as in only 9 of the 35 articles is the term mentioned more than once, and of the remaining 24 , nearly all are either what I would categorize as ascriptive (for example, labeling a scholar's work as "anthropological"), incidental (for example, in a comma-delimited list of disciplines, or in a parenthetical expression), or instead dismissive of anthropology.

${ }^{5}$ This was not an isolated case, as Zappa envisioned a similar production treatment of Captain Beefheart and the Magic Band's 1969 album Trout Mask Replica, which Zappa initially intended to be an "ethnic field recording".

${ }^{6}$ Graham St John, personal communication, October 2012. In the interests of disclosure, I was involved as well with the formation of Dancecult, as the first managing editor.

\section{Acknowledgments}

I wish to acknowledge the generous support of Timothy Murray, Mary Ahl and the Society for the Humanities at Cornell University, which facilitated the research for this project. I thank Jennifer Stoever-Ackerman, Eric Lott, Markus Boon, Rebekah Ahrendt, Larry Witzleben and Graham St. John for productive dialogues that influenced my framing of this essay, and two anonymous reviewers who gave thoughtful and insightful comments. My wife Ladi Dell'aira continues to be supportive in numerous ways, not the least of which is her critical eye for sloppy thinking. Finally I wish to acknowledge the contributions of six teachers of mine whose courses and mentoring shaped my work (and this essay in particular): Gage Averill, Benjamin Brinner, Jocelyne Guilbault, Charles Hirschkind, Mark Slobin, and Bonnie Wade. 


\section{References}

Anderson, Tammy L (2009) Rave Culture: The Alteration and Decline of a Philadelphia Music Scene. Philadelphia: Temple University Press.

Anon (1971) The Popular Music Panels at the PCA Meetings. Popular Music and Society 1 (1): 51-52. http://dx.doi.org/10.1080/03007767108590973

Appadurai, Arjun (1990) Disjuncture and Difference in the Global Cultural Economy. Theory, Culture \& Society 7 (2): 295-310. http://dx.doi.org/10.1177/026327690007002017

Atton, Chris (2011) Fan Discourse and the Construction of Noise Music as a Genre. Journal of Popular Music Studies 23 (3): 324-342. http://dx.doi.org/10.1111/j.15331598.2011.01296.x

Bates, Eliot-

(2009) Ron's Right Arm: Tactility, Visualization, And The Synesthesia Of Audio Engineering. Journal on the Art of Record Production 4 (October). http://arpjournal.com/1358/

(2010) Mixing for Parlak and Bowing for a Büyük Ses: The Aesthetics of Arranged Traditional Music in Turkey. Ethnomusicology 54 (1): 81-105.

(2012) What Studios Do. Journal on the Art of Record Production 7. http://arpjournal.com/2199

Bennett, Samantha (2009) Revolution Sacrilege! Examining The Technological Divide Among Record Producers In The Late 1980s. Journal on the Art of Record Production 5 (July). http://arpjournal.com/601/

Berger, Harris M(1999) Death Metal Tonality and the Act of Listening. Popular Music 18 (2): 161178. http://dx.doi.org/10.1017/S0261143000009028

(2009) Stance: Ideas About Emotion, Style, and Meaning for the Study of Expressive Culture. Middletown, CT: Wesleyan University Press.

Brooks, Daphne A (2010) 'Once More with Feeling': Popular Music Studies in the New Millennium. Journal of Popular Music Studies 22 (1): 98-106. http://dx.doi.org/10.1111/j.1533-1598.2010.01221.x

Brown, Phill (2010) Are We Still Rolling?: Studios, Drugs and Rock " $n$ ” Roll: One Man's Journey Recording Classic Albums. Portland, OR: TapeOp.

Browne, Ray B (1971) "Foreword." Popular Music and Society 1 (1): 2. http://dx.doi.org/10.1080/03007767108590967

Chion, Michel (1994) Audio-vision: Sound on Screen. New York: Columbia University Press.

Clifford, James (1986) Introduction: Partial Truths. In James Clifford and George Marcus Eds. Writing Culture: The Poetics and Politics of Ethnography. Berkeley, CA: University of California Press: 1-26.

Cohen, Sara-

(1991) Rock Culture in Liverpool: Popular Music in the Making. Oxford; New York: Clarendon Press; Oxford University Press.

(1993) Ethnography and Popular Music Studies. Popular Music 12 (2): 123-138. http://dx.doi.org/10.1017/S0261143000005511

Cope, Bill, and Mary Kalantzis (2009) Signs of Epistemic Disruption: Transformations in the Knowledge System of the Academic Journal. First Monday 14 (4). http://firstmonday.org/ojs/index.php/fm/article/view/2309/2163 
Dawe, Kevin (2003) Lyres and the Body Politic: Studying Musical Instruments in the Cretan Musical Landscape. Popular Music and Society 26 (3): 263-283. http://dx.doi.org/10.1080/0300776032000116950

Dent, Alexander Sebastian (2005) Cross-Cultural 'Countries': Covers, Conjuncture, and the Whiff of Nashville in Musica Sertaneja (Brazilian Commercial Country Music). Popular Music and Society 28 (2): 207-227. http://dx.doi.org/10.1080/03007760500045345

Dougan, John (2006) Objects of Desire: Canon Formation and Blues Record Collecting. Journal of Popular Music Studies 18 (1): 40-65. http://dx.doi.org/10.1111/j.1524-2226.2006.00075.x

Duffett, M (2003) False Faith or False Comparison? A Critique of the Religious Interpretation of Elvis Fan Culture. Popular Music and Society 26 (4): 513-522. http://dx.doi.org/10.1080/0300776032000144959

Feld, Steven (1994) From Schizophonia to Schismogenesis: On the Discourses and Practices of World Music and World Beat. In Charles Keil and Steven Feld Ed. Music Grooves. Chicago: University of Chicago Press: 257-289

Finnegan, Ruth H (1989) The Hidden Musicians: Music-making in an English Town. Cambridge: Cambridge University Press.

Fletcher, Michael (2011) The Effect Of Spatial Treatment Of Music On Listener's Emotional Arousal. Journal on the Art of Record Production 5 (July). http://arpjournal.com/832/

Frith, Simon(1982) British Popular Music Research. IASPM UK Working Paper No. 1. (2007) A Journal on the Art of Record Production. Journal on the Art of Record Production 1 (February). http://arpjournal.com/486/

Frith, Simon and Horne, Howard (1987) Art Into Pop. London: Methuen.

Gerber, Heidi (2011) Adult MP3 Users' Perspectives On Past And Present Consumer Audio Technology: Does The Music Still Matter? Journal on the Art of Record Production 5 (July). http://arpjournal.com/866/

Goertzen, Chris, and María Susana Azzi (1999) Globalization and the Tango. Yearbook for Traditional Music 31: 67-76. http://www.jstor.org/stable/767974

Grenier, Line, and Jocelyne Guilbault (1990) 'Authority' Revisited: The 'Other' in Anthropology and Popular Music Studies. Ethnomusicology 34 (3): 381-397. http://www.jstor.org/stable/851624

Hartman, Kent (2012) The Wrecking Crew: The Inside Story of Rock and Roll's Bestkept Secret. New York: St. Martin's Press.

Hodgson, Jay (2011) Lateral Dynamics Processing In Experimental Hip Hop: Flying Lotus, Madlib, Oh No, J-Dilla And Prefuse 73. Journal on the Art of Record Production 5 (July). http://arpjournal.com/880/

Howard, Denis (2008) From Ghetto Laboratory to the Technosphere: The Influence of Jamaican Studio Techniques on Popular Music. Journal on the Art of Record Production 3 (November). http://www.artofrecordproduction.com/content/view/164/109/

Inglis, lan (2003) 'Some Kind of Wonderful': The Creative Legacy of the Brill Building. American Music 21 (2): 214-235. http://www.jstor.org/stable/3250565

Jackaway, Gwenyth (1999) Selling Mozart to the Masses: Crossover Marketing as Cultural Diplomacy. Journal of Popular Music Studies 11-12 (1): 125-150. http://dx.doi.org/10.1111/j.1533-1598.1999.tb00006.x 
Jacques, Geoffrey (2001) A Roundtable on Ken Burns's Jazz. Journal of Popular Music Studies 13 (2): 207-225. http://dx.doi.org/10.1080/152422201753331207

Juno, Andrea and Vale, Vivian (1983) Industrial Culture Handbook. San Francisco, CA: RE/Search Publications.

Keil, Charles (1985) People's Music Comparatively: Style and Stereotype, Class and Hegemony. Dialectical Anthropology 10 (1-2): 119-130. http://dx.doi.org/10.1007/BF00244253

Kronengold, Charles (2005) Accidents, Hooks and Theory. Popular Music 24 (3): 381397. http://dx.doi.org/10.1017/S0261143005000589

MacFarlane, Thomas (2009) Magical Mystery Tour: Mono or Stereo? Journal on the Art of Record Production 4 (October). http://arpjournal.com/1362/

Marcus, George E., and Michael M. J. Fischer (1986) Anthropology as Cultural Critique: An Experimental Moment in the Human Sciences. Chicago: University of Chicago Press.

Maxwell, William J. (2004) Ralph Ellison and the Constitution of Jazzocracy. Journal of Popular Music Studies 16 (1): 40-57. http://dx.doi.org/10.1111/j.00224146.2004.00010.x

Mclntyre, Phillip (2008) The Systems Model Of Creativity: Analyzing The Distribution Of Power In The Studio. Journal on the Art of Record Production 3 (November). http://arpjournal.com/686/.

Meintjes, Louise (2003) Sound of Africa!: Making Music Zulu in a South African Studio. Durham: Duke University Press.

Morrow, Guy (2012) Creative Conflict In A Nashville Studio: A Case Of Boy \& Bear. Journal on the Art of Record Production 6 (June). http://arpjournal.com/1838/

Moylan, William (2009) Considering Space in Music. Journal on the Art of Record Production 4 (October). http://arpjournal.com/1379/

Mynett, Mark (2012) Achieving Intelligibility Whilst Maintaining Heaviness When Producing Contemporary Metal Music. Journal on the Art of Record Production 6 (June). http://arpjournal.com/1858/

Nettl, Bruno (2010) Nettl's Elephant: On the History of Ethnomusicology. Urbana: University of Illinois Press.

Novak, David (2008) 2.5×6 Metres of Space: Japanese Music Coffeehouses and Experimental Practices of Listening. Popular Music 27 (1): 15-34 http://dx.doi.org/10.1017/S0261143008001517

Ortner, Sherry B. (2006) Anthropology and Social Theory: Culture, Power, and the Acting Subject. Durham: Duke University Press.

PCAACA (2013) PCAACA - Popular Culture Association and American Culture Association. http://pcaaca.org/about/history-and-overview/ Accessed: 20 Feb 2013.

Paterson, Justin (2007) Phase Experiments In Multi-Microphone Recordings: A Practical Exploration. Journal on the Art of Record Production 1 (February). http://arpjournal.com/1803/

Porcello, Thomas (1998) 'Tails Out': Social Phenomenology and the Ethnographic Representation of Technology in Music-Making. Ethnomusicology 42 (3): 485-510. http://www.jstor.org/stable/852851

Prato, Paolo (1990) On the Road Again: Rituals of Effervescence in the Contemporary Urban Soundscape. OneTwoThreeFour 9: 5-11.

Ribac, François (2007) From the Scientific Revolution to Rock: Toward a Sociology of Feedback. Journal on the Art of Record Production 1 (February).

http://arpjournal.com/368/ 
Sarbanes, Janet (2006) Musicking and Communitas: The Aesthetic Mode of Sociality in Rebetika Subculture. Popular Music \& Society 29 (1): 17-35.

http://dx.doi.org/10.1080/03007760500142738

Schafer, R. Murray (1977) The Tuning of the World. New York: A. A. Knopf.

Scheurer, T. E (1996) The Beatles, the Brill Building, and the Persistence of Tin Pan Alley in the Age of Rock. Popular Music and Society 20 (4): 89. http://dx.doi.org/10.1080/03007769608591646

Schmidt, Joshua (2012) Full Penetration: The Integration of Psychedelic Electronic Dance Music and Culture into the Israeli Mainstream. Dancecult: Journal of Electronic Dance Music Culture 4 (1): 38-64. http://dj.dancecult.net/index.php/journal/article/view/114

Scott, Ken, and Bobby. Owsinski (2012) Abbey Road to Ziggy Stardust: Off the Record with the Beatles, Bowie, Elton \& So Much More. Los Angeles: Alfred Music Pub.

Sheehan, Thomas W (2007) Iggy's Blues. Journal of Popular Music Studies 19 (2): 133-156. http://dx.doi.org/10.1111/j.1533-1598.2007.00117.x

Solomon, Thomas-

(2005) 'Living Underground Is Tough': Authenticity and Locality in the Hip-hop Community in Istanbul, Turkey. Popular Music 24 (1): 1-20.

http://dx.doi.org/DOI:10.1017/S0261143004000273

(2012) Theory and Method in Popular Music Analysis: Text and Meaning. Studia Musicologica Norvegica 38 (1): 86-108.

St John, Graham-

(2001) Alternative Cultural Heterotopia and the Liminoid Body: Beyond Turner at ConFest. The Australian Journal of Anthropology 12 (1): 47-66.

http://dx.doi.org/10.1111/j.1835-9310.2001.tb00062.x

(2008) Trance Tribes and Dance Vibes: Victor Turner and Electronic Dance Music Culture. In Graham St John Ed, Victor Turner and Contemporary Cultural

Performance. New York: Berghahn Books: 149-173.

(2009) Neotrance and the Psychedelic Festival. Dancecult: Journal of Electronic Dance Music Culture 1 (1): 35-64.

http://dj.dancecult.net/index.php/journal/article/view/11

(2012) Seasoned Exodus: The Exile Mosaic of Psyculture. Dancecult: Journal of Electronic Dance Music Culture 4 (1): 4-37.

http://dj.dancecult.net/index.php/journal/article/view/111

Sterne, Jonathan (2003) Bourdieu, Technique and Technology. Cultural Studies 17

(3/4): 367-389. http://dx.doi.org/10.1080/0950238032000083863a

Straw, Will (2010) Cultural Production and the Generative Matrix: A Response to Georgina Born. Cultural Sociology 4 (2): 209-216.

http://dx.doi.org/10.1177/1749975510368472

Tagg, Philip-

(1979) Kojak: 50 Seconds of Television Music. Ph.D. Dissertation, Gøteborg University.

(1985a) Why IASPM? Which Tasks? In David Horn Ed. Popular Music Perspectives 2, pp 501-507. Gøteborg; Exeter: IASPM.

http://www.tagg.org/articles/iasptask83.html

(1985b) Address on the State of the Association. International Association for the Study of Popular Music, IASPM $3^{\text {rd }}$ Annual Conference. Montréal, QE.

http://www.tagg.org/articles/montreal.html 
(2011) Caught on the Back Foot: Epistemic Inertia and Visible Music. IASPM@Journal 2 (1-2): 3-18.

http://www.iaspmjournal.net/index.php/IASPM Journal/article/view/556

Tagg, Philip, and Keith Negus (1992) The Primary Text: Back to Square One? IASPM UK Newsletter, September.

Théberge, Paul (1990) Democracy and Its Discontents: The MIDI Specification. OneTwoThreeFour 9: 12-34.

Vale, Vivian and Juno, Andrea (1989) Modern Primitives: An Investigation of Contemporary Adornment \& Ritual. San Francisco, CA: Re/Search Publications.

Wæver, Ole (1998) The Sociology of a Not So International Discipline: American and European Developments in International Relations. International Organization 52 (4): 687-728. http://dx.doi.org/10.1162/002081898550725

Wallach, Jeremy (2003) The Poetics of Electrosonic Presence: Recorded Music and the Materiality of Sound. Journal of Popular Music Studies 15 (1): 34-64. http://dx.doi.org/10.1111/j.1533-1598.2003.tb00114.x

Wicks, Sammie Ann (1998) America's Popular Music Traditions as 'Canon-Fodder'. Popular Music and Society 22 (1): 55-89. http://dx.doi.org/10.1080/03007769808591697

Zak, Albin-

(2001) The Poetics of Rock: Cutting Tracks, Making Records. Berkeley: University of California Press.

(2012) The State Of The Art And The State Of The Discipline. Journal on the Art of Record Production 6 (June). http://arpjournal.com/2010/ 